\title{
Review of Mustajoki, Arto Samuel, Ekaterina Protassova and Maria N. Yelenevskaya (eds.). 2020. The Soft Power of the Russian Language. Plucentricity, Politics and Policies. Abingdon: Routledge. ISBN 9780367183660
}

\author{
Anastassia Zabrodskaja \\ Tallinn University / University of Tartu \\ Tallinn / Tartu, Estonia
}

For Citation:

Zabrodskaja, Anastassia. 2020. Review of Mustajoki, Arto Samuel, Ekaterina Protassova and Maria N. Yelenevskaya (eds.). 2020. The Soft Power of the Russian Language. Plucentricity, Politics and Policies. Abingdon: Routledge. Russian Journal of Linguistics 24 (1). 205-211. DOI: 10.22363/2687-0088-2020-24-1-205-211.

Рецензия

\section{Рецензия на книгу Mustajoki, Arto Samuel, Ekaterina Protassova and Maria N. Yelenevskaya (eds.). The Soft Power of the Russian Language. Plucentricity, Politics and Policies. Abingdon: Routledge, 2020. ISBN 9780367183660}

\author{
А.Н. Забродская \\ Таллиннский университет / Тартуский университет \\ (Таллинн / Тарту, Эстония)
}

Для цитирования:

Zabrodskaja, Anastassia. 2020. Review of Mustajoki, Arto Samuel, Ekaterina Protassova and Maria N. Yelenevskaya (eds.). 2020. The Soft Power of the Russian Language. Plucentricity, Politics and Policies. Abingdon: Routledge. Russian Journal of Linguistics 24 (1). 205-211. DOI: $10.22363 / 2687-0088-2020-24-1-205-211$.

As the $20^{\text {th }}$-century French sociologist Pierre Bourdieu suggests, there are four different forms of capital: economic capital (money and ownership), cultural capital (education), social capital (social networks and relationships) and symbolic capital 
(prestige). This book is about the Russian language as a "soft power" tool, according to the book's title, but I would propose that it is more about Russian as a capital, if we look specifically at the titles of the sections: Part 1. "Russian as a communicative tool: lingua franca, intermediator or something else?", Part 2. "The Russianlanguage legacy", Part 3. "The Russian-speaking diaspora", and Part 4. "New trends in the functioning of the Russian language". In other words, the book deals with the status of Russian and the planning of the status. It is about corpus planning and acquisition planning, top-down and bottom-up, providing a wide range of examples, from both the official and the grass-roots levels. This collection allows the reader to travel around the globe in search of Russian's soft power in a variety of countries: in the post-Soviet area (Georgia, Armenia, Azerbaijan, Estonia, Latvia, Lithuania, Belarus, Ukraine, Kazakhstan and Kyrgyzstan), in Western Europe (France, Germany, Finland, Great Britain and Sweden) and in countries closely related to Russia culturally, historically and economically through past or recent intensive migration (the US, Canada and Cyprus) and/or through membership in political and economic unions and strategic partnerships (in South America). Japan can be considered a cherry on the cake in this beautiful mosaic of countries.

This volume consists of 21 chapters and the above-mentioned four parts follow one another logically. In my review, I comment upon what was missing for me as a reader (especially in Part 2).

Arto Mustajoki, Ekaterina Protassova, and Maria Yelenevskaya make an attempt to list the challenges of the pluricentric development of Russian, while highlighting the linkages among the varieties of the Russian language away from the Metropolis, as they state on page 9: "the main contribution of the volume in advancing the theory of linguistic pluricentricity by providing a multifaceted and empirically based description of the varieties of Russian differing in the status and vitality, intensity of use in the public sphere and relevance for the speakers' identity". In this collection, there are lots of modern instances of the close connections among the diaspora and mainstream Russian languages, identity, and challenging and sometimes dramatic attitudes. Unfortunately, there is no concluding chapter to summarise how the Russian-speaking speech communities, diasporas and individuals try to build their multiple identities as they cope with the demands of their particular states' official legislation and actual linguistic environments.

Vladimir M. Alpatov illuminates the history of the internationalisation of the Russian language and concludes that interests in alphabet and script choice arise with changes in the political and cultural orientations of ruling elites. This chapter seems a little out of date, as Alpatov says "a new cycle of instability might be ahead leading to Latinization in Kazakhstan" (page 19), although Latinisation of the Kazakh alphabet started in 2017 (as loudly declared with the aim of consolidating the Kazahh national identity, but in fact it may have been merely an attempt by proWestern politicians to take Kazakhstan out of the linguistic and cultural influence of the Russian Federation). This chapter is short but it is a good brief introduction 
to Soviet language legislation patterns that might be used with undergraduate students when discussing Soviet top-down language policy and bottom-up reactions to it.

Implicit in the chapter on the democratisation of Russian by Arto Mustajoki is the idea that the evolution of contemporary Russia's Russian can be seen as an instrumental tool, as it allows standard Russian to expand with the help of loanwords, new creations and the linguistic creativity of its speakers. Here presidents of Russia are mentioned as triggers for the "brutal and colloquial lexicon" exposure in the case of Putin, and a rise in the popularity of "youth slang" due to Medvedev. While reading this chapter, I had a feeling that the reason it was written was Mustajoki's desire to overcome the compelling ignorance of many Russian linguists, as well as of official language policy makers, that different varieties of Russian have clearly been emerging in their own speech communities.

There is still a developing (although more popular than scientific) discourse about the differences, not necessarily clearly either linguistic or cultural, between Russia's Russian-speakers and Russian-speaking diasporas (or communities). The second part of this exciting book introduces the Russian-language legacy in postSoviet countries with substantial or even only small numbers of Russians and Russian-speaking communities which appeared there for different historical-political reasons in the past, and especially during the Soviet era. I remember very well my personal interactions with Aneta Pavlenko, who made the first efforts to put together an overview of Russian language use and the current Russian state from the departure point of the break-up of the USSR in 1991 (see Pavlenko 2008). She mentioned the challenge of finding authors in the particular countries who dealt with specific questions as insiders or outsiders. Here again some countries are missing, in particular Moldova, Tajikistan, Turkmenistan and Uzbekistan. Reading the second part of the book, one wishes to get acquainted with the ways post-Soviet countries are similar but also different in top-down policies and bottom-up language practices with regard to these countries' titular languages, as well as Russian and minority languages. How have official and grassroots attitudes towards these languages changed? What are the levels of Russian language maintenance and to what degree have titular- and Russian-language speakers shifted to the titular languages in everyday practices?

Russians form a group that differs from typical immigrant communities in having been a dominant group which has lost its high status, but their situation also differs from typical postcolonial settings in that the Russian language has not retained its powerful position. Consider Blommaert (2013: 40), who rightly acknowledges that "communication in the public space is communication in a field of power". In terms of reaching some general conclusions, there are rich empirical materials presented in the book being reviewed: these expand and show how Russian reinforces and implements new forms in the public sphere, also touching upon some dark sides of nationalism in newly independent states, where institutional and 
non-official support is enjoyed by the regained and reinvigorated impetus of official languages.

If we turn to the titles of the nine chapters for more detailed examples, these are "Language Policy in Relation to the Russian Language in Georgia before and after the Dissolution of the Soviet Union" by Kakha Gabunia and Ketevan Gochitashvili, "Russian in Armenia: Between Thriving and Surviving" by Suren T. Zolyan and Karen S. Hakobyan, "Russian in Azerbaijan: Changing Practices and Emerging Paradigms" by Jala Garibova, "Variability in the Russian Diaspora Speech of Estonia" by Jelisaveta Kostandi, Irina Külmoja and Oksana Palikova, "The Russian Language in Latvia-The Historic Linguistic Situation" by Pāvels Jurs and Alīda Samuseviča, "The Russian Language of the Lithuanian Republic as Reflected in Mass Media Discourse" by Birute Sinochkina, "The Russian Language in Belarus and Ukraine" by Jan Patrick Zeller and Dmitri Sitchinava, "The Russian Language in Kazakhstan in the 21st Century" by Damina Shaibakova, and "Russian Language in Kyrgyzstan: Status, Functioning and Collisions between Languages" by Mamed D. Tagaev and Ekaterina Protassova. Part 2 covers 10 countries, as Ukraine and Belarus are combined into one case study. I will discuss the book's title later but I believe that probably in Soft Power of Russian there is no independent study on Ukraine, which is sad because sociolinguistics as a scientific branch must be an independent enterprise, not an area of political manipulation. But there is a problem with "soft power", as all sociolinguists know the expression from the famous Yiddish expert and linguist Max Weinreich, who said that "a language is a dialect with an army and navy". Some languages have soft power, while others do not. What I as a meticulous reader particularly missed in Part 2 were cross-references among the case studies, although I do understand that the editors and the authors were trying to briefly show intra-linguistic and extra-linguistic forces at work in sociolinguistic situations and the social life of Russians in the former USSR countries included in the volume (probably a reader should have the background to make such connections independently).

Part of the ideological underpinning is the discussion about the Russian-speaking diaspora and the preservation of its linguistic and cultural heritage. Strong networks support language and cultural maintenance, while weak ties lead to language and identity shift. Collectivistic cultures have stronger networks than individualistic cultures, and Russian culture is considered to be collectivist according to Hofstede's definition. Typical observations are provided in Part 3 by Irina Kor Chahine in "The Russian Language in France: from the Russian Community to the National Education System"; by Katharina Hamann, Kai Witzlack-Makarevich and Nadja Wulff in "Russian in Germany"; by Johanna Viimaranta in "Russian and its Speakers in Finland", by Veronika Makarova in "The Russian Language in Canada", by Olga Rovnova in "The Russian Dialects Outside Russia: The Situation in South America"; and by Oksana Morgunova (Petrunko) and Renat T. Zinnurov in "Connected by Digital Imagination: Discourses of Belonging and Community Building of Russophone Migrants in the USA and Great Britain". 
Although power relations, the overt and covert prestige of Russian and titular or mainstream languages, ideologies, discourses about these languages, shared values etc. matter, we cannot always predict what will occur in everyday multilingual communication. When a reader turns to matters of the Russian language presented under the new trends [my emphasis - A.Z.] in its functioning, it becomes clear that a closer look at individual [my emphasis - A.Z.] language planning allows the reader to find new facts. Without an investigation of individual multilingual oral /writing practices and repertoires, it is impossible to get a full picture of the (non)transmission of Russian and concrete examples might be drawn from the following topics discussed in the book's Part IV: Russian as a heritage language in the context of immigration (Tanya Ivanova-Sullivan), family language policy based on the example of Cyprus and Sweden (Natalia Ringblom and Sviatlana Karpava), and Russian as foreign language education in Japanese high schools (Sachiko Yokoi Horii).

To be honest, the only thing that I totally dislike (perhaps even despise) about this book is its title: The Soft Power of the Russian Language. In our world of binary oppositions and prototypically exclusive dimensions, i.e. soft $v s$. hard, and power $v s$. weakness (inability, incapacity and impotence), I would rather talk about Russian language ecology (and especially, considering Einar Haugen's theory of the ecology of language (1972), speakers, who are important as they learn the language, use it and transmit it to others). Probably the editors had a similar feeling because on page 10 they say that they "hope that a panoramic view of the ecology of Russian [my emphasis - A.Z.] today will contribute to a greater tolerance among readers for language variation" but the use of the term was due to (probably political) fashion. It is especially funny to hear about Russian soft power in the discourse of Russia's elites as it is considered to involve gatherings around a samovar in numerous Russkiy Mir Foundation houses across the globe. To cite John Edwards (2009: 25), who slightly adapted Orwell (1945/1965: 178): "one has to belong to intelligentsia to produce or respond favourably to this sort of thing; no ordinary person could be so silly." Maybe one day the understanding that it is indeed natural that the changing nature of Russian, its variability and especially its market-driver commodification in service-oriented industries is hardly compatible with standardisation, and prestige is confronted by authenticity in a multilingual global market, where languages as symbolic linguistic resources have gained salience and value. This understanding will be facilitated by the insights provided by this contribution (hopefully among future readers).

Arto Mustajoki, Ekaterina Protassova and Maria Yelenevskaya state without a trace of doubt that the "Russian diaspora could never boast a unity of goals and attitudes to the country of origin. It is the language and the desire to maintain it that have always served as the diaspora's primary unifying factor" (page 5). Here I would add that as a language is the core of culture and both enables people to reduce their uncertainty and to feel a sense of belonging (and people do need an emotional attachment to a collective group either in the country where they live or abroad), it 
would be fantastic to have somebody edit a collection of Russian culture transmissions (but bottom-up, among ordinary individuals, not with the help of all those "cultural institutions") across the same choice of countries and even in new regions. This is interesting to consider in our contemporary globalised society, where the number of mixed families is increasing. In many of these micro-collectives Russian functions as one of the arbitrary elements of shared communication, or a semiosphere. The mode of communication and the experience of such families will definitely have an impact on the intergenerational transmission of the Russian language(s) and culture(s).

(C) Anastassia Zabrodskaja, 2020

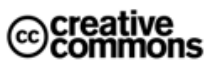

This work is licensed under a Creative Commons Attribution 4.0 International License https://creativecommons.org/licenses/by/4.0/

\section{REFERENCES}

Blommaert, Jan. 2013. Ethnography, Superdiversity and Linguistic Landscapes. Bristol, Multilingual Matters.

Edwards, John. 2009. Language and Identity: An Introduction. Cambridge, Cambridge University Press.

Haugen, Einar. 1972. The ecology of language. A. S. Dil (ed.), The Ecology of Language. Essays by Einar Haugen. Stanford, Stanford University Press.

Orwell, George. 1945/1965. Notes on nationalism. In Decline of the English Murder and Other Essays. Harmondsworth, Penguin. [First published in Polemic 1, October 1945.]

Pavlenko, Aneta. (ed.). 2008. Multilingualism in post-Soviet countries. International Journal of Bilingual Education and Bilingualism 11 (3\&4).

\section{Bionote:}

ANASTASSIA ZABRODSKAJA $(\mathrm{PhD})$ is a Professor of Intercultural Communication at Tallinn University. In 2014-2019 she worked as a Senior Research Fellow in Sociolinguistics at the University of Tartu, in the project IUT20-3 "Sustainability of Estonian in the Era of Globalisation". In 2013-2017 she participated in the COST project "New Speakers in a Multilingual Europe: Opportunities and Challenges" and in 2019-2023 — in the COST project "The European Family Support Network: A Bottom-up, Evidence-Based and Multidisciplinary Approach". Her research deals with identity, intercultural communication, code-switching and linguistic landscape. She has published a monograph and numerous articles on bilingualism and language contacts.

\section{Contact information:}

E-mail: anastassia.zabrodskaja@gmail.com

Adress: Tallinn University Baltic Film, Media, Arts and Communication School Narva mnt 27, room N430, 10120 TALLINN, Estonia

ORCID http://orcid.org/0000-0001-8082-3549 
Сведения об авторе:

АНАСТАСИЯ НИКОЛАЕВНА ЗАБРОДСКАЯ $(\mathrm{PhD})$ - профессор межкультурной коммуникации Таллиннского университета, в 2014-2019 старший научный сотрудник в области социолингвистики Института эстонского и общего языкознания в Тартуском университете, участник проекта IUT20-3 "Sustainability of Estonian in the Era of Globalisation". В 2013-2017 участвовала в Европейском COST проекте "New Speakers in a Multilingual Europe: Opportunities and Challenges", а в 2019-2023 в Европейском COST проекте "The European Family Support Network: A Bottom-up, Evidence-Based and Multidisciplinary Approach". Сфера научных интересов идентичность, межкультурная коммуникация, переключение кодов и языковой ландшафт. Автор монографии и многочисленных статей по билингвизму и языковым контактам.

\section{Контактная информация:}

E-mail: anastassia.zabrodskaja@gmail.com

Aдрес: Tallinn University Baltic Film, Media, Arts and Communication School Narva mnt 27, room N430, 10120 TALLINN, Estonia

ORCID http://orcid.org/0000-0001-8082-3549 